\title{
A REFLECTIVE PERSPECTIVE TOWARDS AGRICULTURAL INFORMATION-BASED SYSTEM DEVELOPMENT IN GENERAL RURAL CHINA AND FARMERS' ECONOMIC ASSOCIATION AS THE ENTRY POINT OF ICTS
}

\author{
Miao $\mathrm{Ji}^{1,{ }^{*}}$,Ting Zuo ${ }^{1}$,Eamon Leninhan ${ }^{2}$ \\ ${ }^{1}$ College of Humanities and Development, China Agriculture University, Beijing, 100094 \\ ${ }^{2}$ Center for Sustainable Livelihoods, University College Cork, Ireland \\ * Corresponding author, Address: College of Humanities and Development, China Agriculture \\ University, Beijing, 100094, P. R. China, Tel: +353876194121, +8613010774671, Fax: \\ +353214903358,Email: watermiao2003@hotmail.com
}

\begin{abstract}
The information-based agricultural system plays a profound role in agricultural economic and social development in long term. There are various practices worldwide, both successful and unsuccessful. In recent years new technologies blossomed, if those new technologies succeed in the developed world, does it hold true for China? The alternative choices in informationbased system development should be noticed in China. This article argues that China's development policy should choose the way that adapts to China's circumstances, not totally adopt the western way. In the current situation of general rural China, the theme of information-based agricultural system needs to be further addressed. It is suggested that the Farmers' Economic Association can be considered as one of the most accessible entry-points for further development way.
\end{abstract}

Keywords: Farmers' Economic Association, ICTs, Information-based system

Please use the following format when citing this chapter:

Ji, M., Zuo, T. and Leninhan, E., 2009, in IFIP International Federation for Information Processing, Volume 295, Computer and Computing Technologies in Agriculture II, Volume 3, eds. D. Li, Z. Chunjiang, (Boston: Springer), pp. 1825-1834. 


\section{SMALL-SCALE FARMERS, AGRICULTURE DEVELOPMENT AND INFORMATION}

Small-scale farming is a typical feature in rural China. Agriculture development policies should aim at small-scale farmers. In research on small-scale farmers in Africa (Wapakala,1982), several agriculture development areas have impacts on the productivity and on the income of small-scale farmers; these areas are covering agriculture extension, local farmer participation, credit, marketing, social services, project administration and training. Hence, development in these areas will be meaningful for small-scale farmers.

In agriculture development, information plays active roles. Many researches have demonstrated the profound contributions of information towards agriculture development and poverty reduction. (Kalusopa, 2005) pointed out agricultural information has become core dynamic factor for rapid rural development. Agricultural development activities are based on the utilization of information. (Williams \& Williams, 1987) highlighted the importance of the information dissemination, and the relationships between information transfer and the agricultural development. Referring to information utilization, (Richardson, 1997) deemed when information or knowledge was harnessed by strong organizations of small producers, strategic planning could be used to provide members with lower cost inputs, better storage facilities, improved transportation links and collective negotiations with buyers. (Mchombu, 2003), described a rural development information centre model, based on broad information strategy, competent information facilitators, a multi-channel approach to information dissemination, and the participation of different rural groups.

Though different researchers have different research perspectives, the above research demonstrates implicit linkages across small-scale farmers, agriculture development and information. Farmers, as a dynamic factor, play roles in information dissemination and agriculture development; information, as a new emerging factor, contributes sufficiently to rapid agriculture development; agriculture development will turn out to be favorable to farmers. In this process, infrastructure is not the absolute affecting factor in terms of information-based system establishment; institution building is an alternative option for small-scale farmers except for infrastructure building. The relationships can be shown in Fig.1: 


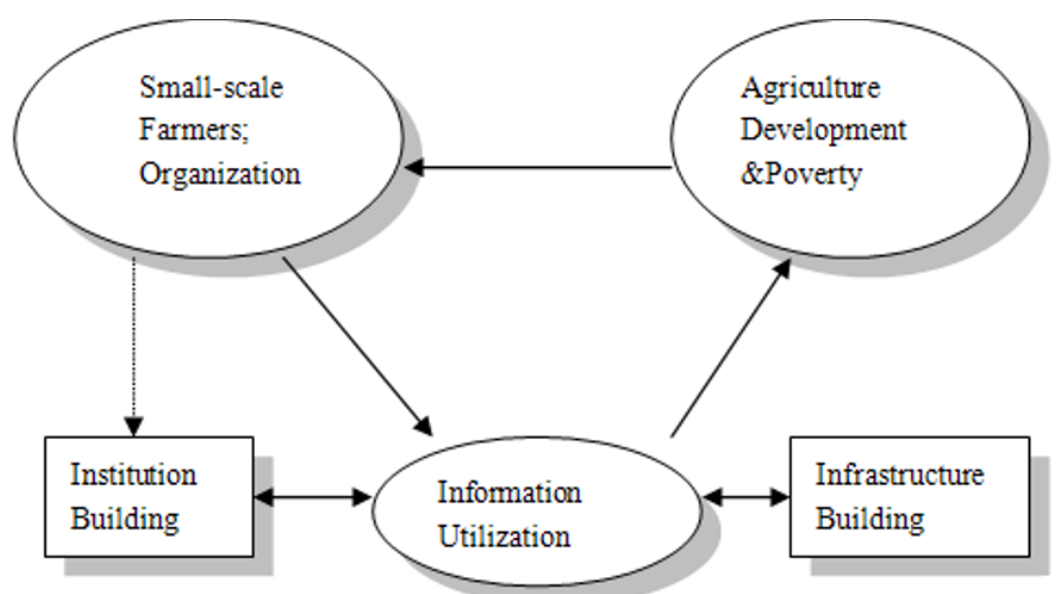

Fig.1: Relationships between small-scale farmers, information and agriculture development

\section{THE APPLICATIONS OF ICTS WORLDWIDE}

In the process of information utilization, there are a lot of experiences of ICTs (information and communication technologies) worldwide. The experiences of ICTs have shown that many new ICTs technologies emerge in the form of e-techniques, including group discussion via Internet forums and bulletin boards, voter guides, e-mail, instant messaging, blogs, CDs, video, film, PC-produced publications, community broadcasting, and other new media; rapid group mobilization via e-mail, mobile cell phones, instant Internet messaging; controls on spam, access to Web sites and other content; interactive voting and polling via the Internet, digital TV, text messaging; government, public agencies, NGOs and the politicians using all ICTs to inform, communicate and consult with the public (Cfr. UNESCO,2004). Though it seems these technologies contribute to the efficiency of information dissemination among different people and different organizations. While an important point which needs to be identified is whether human skills can feed the technologies, and whether these technologies can feed local people real needs.

The usage of ICTs in both developed and developing countries have confronted some barriers. According to (Kalusopa, 2005; Obijiofor, 1998; Agriculture and Agri-Food Canada, 2003), in terms of the information development, several challenging factors can be summarized, these factors are social culture and local basic needs, appropriate institution and systems, 
users' capacity building and skills improvement, infrastructure establishment, management skills, and the appraisal method improvement, etc.

\section{CHALLENGES IN INFORMATION-BASED SYSTEM IN CHINA: FROM A GENERAL REFLECTIVE PERSPECTIVE}

Generally speaking, in the process of development in China, main policies have been based on the 'giving priority to efficiency with due consideration to fairness' principle, the same happened in the information development policy design. An industrialization characterized developing path depends more on advanced sciences and technologies. Hence, referring to what is information-based system, (Daoliang, 2007) has given a definition that it is 'a process characterized by application of mobile and computer technologies in agriculture production, rural life and social management', 'In this process, human beings can employ high technologies to exploit information resources sufficiently, in order to promote agricultural economic development and social development'. In the current developing path mentioned above, this definition of information-based system seems feasible, while when considering the development path from a reflective perspective, such definitions need to be reconsidered.

During the process of information-based system establishment, five main challenges emerge in the general picture:

First, there is a challenge of infrastructure limitation in poor rural areas. In the current situation in rural China, limited by the infrastructure constraints, especially in many poor rural areas, human factors are still the main means of collecting and disseminating information (Miao, 2008). Hence, it will be meaningful to investigate the human factors' roles, as the basis for further information policy design. Computer and mobile infrastructure shouldn't be simply set as the indicators to measure the developing level of information-based agricultural system.

Second, there is a dramatic gap of information infrastructure building between east and west areas in China. In this research, the comparison data on rural informationize index can be divided into two groups, one is typical east developed areas constituted by Beijing, Shanghai and Zhejiang, the other group is typical west underdeveloped areas which are comprised by Yunnan, Guizhou and Tibet. The index of national average level is set in the middle. From the comparison, it shows the extreme big gap between these two groups. Take Beijing and Tibet for example, Beijing's informationize index is three times Tibet's. From the anti-poverty function of information, olicies should be adjusted more to the west characterized poor and main 
agriculture areas. It is the time to implement the development principle, that is, 'consideration for fairness'.

Table 1: Development gap between east area and west area in China

\begin{tabular}{llllllll}
\hline Areas & Beijing & Shanghai & Zhejiang & Average & Yunnan & Guizhou & Tibet \\
\hline Index & 68.25 & 67.8 & 60.69 & 40.53 & 28.33 & 27.7 & 20.74 \\
\hline
\end{tabular}

Source of Data: Daoliang, 2007

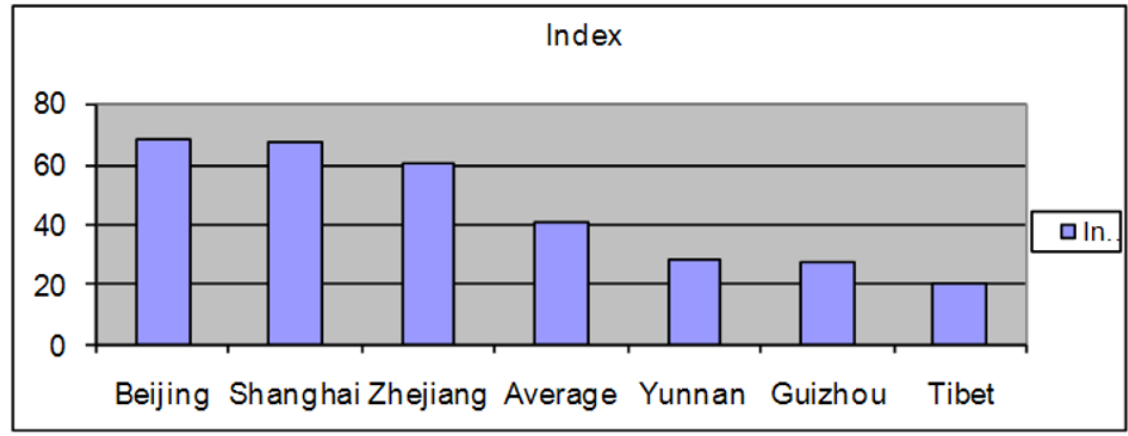

Third, according to information supply system, this is characterized as scattered, poorly developed and unfocused in the current supply system. It seems lack of co-ordinate efforts in the establishment process leading to the duplication of efforts among different information developing entities.

Fourth, the traditional top-down development model burdens the government and it usually causes neglect of farmers' real and diverse needs.

Fifth, cultural factor is always neglected in policy planning and implementation. In rural areas, compared with traditional information and communication ways, which are formed in the long history, characterized by certain cultural background, to create transformative space for new information and communication technologies is not easy. The main point is to consider the cultural and history factors.

Information establishment is a systematic process. These five challenges mentioned above are just summarized from a general perspective. There are still other diverse challenges in practice, which need to be addressed and shared further in practice. 


\section{OPTIONS AND DIRECTIONS FOR THE FUTURE: FARMERS' ECONOMIC ASSOCIATION AS ENTRY POINT}

The general development of ICTs in rural areas is still at an original stage with many challenges in current period. While from the worldwide experiences of ICTs application in rural areas, it seems that two ways can be figured out for information-based system establishment in the future, first, developing totally along with the Western way without considering any influences; second, developing according to certain local circumstances in China, at the same time adapting appropriate technologies to local development. From my point of view in this paper, the second choice seems more reasonable. The adaptive entry point and institution arrangement should be explored in this process.

According to (Daoliang, 2007), there are mainly five kinds of implementing entities in an agricultural information-based system, these are, government, including central government and local government, agricultural companies, scientific institutions and universities, farmers' associations and farmers' households, different entities play different important roles in information-based system building. In this paper, when referring to the development options of the information-based systems establishment in China, Farmers' Economic Associations have been decided as an entry point for a long-term information-based agricultural system development strategy, especially in the underserved rural areas.

Farmers' Economic Association is an association of persons, who work together to achieve certain commercial objectives. As an interest organization, usually is created from below by individuals to satisfy their common needs, the objective of which can cover many aspects, mainly reflecting social values. Besides, farmers' economic association is usually understood as an economic activity owned and managed by the members to promote member's needs.

For the discussion about the general challenges of information-based system development in China, Farmers' Economic Association, as a kind of institutional arrangement, plays active roles in information dissemination under the poor infrastructure conditions, and has the cultural advantage which will help to create new space for using new information and communication technologies, it also has the advantage in feeding farmers' diverse and real needs. However, there is still other macro 'glass ceiling' difficult to be broken just depending on Farmers' Economic Association, such as the gap between information infrastructure building and the challenge in the information supply system. Strategic, long-term and sustainable approach should be taken into account by government and policy decision makers. 
Farmers' Economic Association, as 'union is strength' which in the process of rural reform, plays very important roles in information dissemination.

Firstly, individual farmer management institution, with low productivity, and disperse small-scale farmers situation, can hardly be adapted to the market situation as the development of market economy. Agricultural information has emerged as very important linkages between small-scale farms and 'big market'. The development of Farmers' Economic Association plays positive roles in new technology extension, technologic transfer and dissemination of technology and market information.

Secondly, Farmers' Economic Association has the advantage of human factor in information dissemination. According to case studies in some undeveloped rural areas (Miao, 2008), there is a typical feature in information dissemination inner and outside of farmers' economic association, that is, human factors are still the main subject to collect and disseminate information, including market and technology information.

Thirdly, different entities have their own advantages and disadvantages in the establishment of information-based system.

Table 2: Comparison of advantages and disadvantages among different entities

\begin{tabular}{lll}
\hline Different entities & \multicolumn{1}{c}{ Advantages } & \multicolumn{1}{c}{ Disadvantages } \\
\hline Government & $\begin{array}{l}\text { Sufficient financial resources; } \\
\text { Supply information }\end{array}$ & $\begin{array}{l}\text { Burdened by so many tasks; } \\
\text { Inefficient top down policies }\end{array}$ \\
\cline { 2 - 3 } $\begin{array}{l}\text { Agricultural } \\
\text { companies }\end{array}$ & $\begin{array}{l}\text { Guide farmers in planting and } \\
\text { breeding areas; } \\
\text { Supply information }\end{array}$ & $\begin{array}{l}\text { Interests deviation from } \\
\text { farmers when facing risks }\end{array}$ \\
\cline { 2 - 3 } $\begin{array}{l}\text { Scientific institution } \\
\text { and universities }\end{array}$ & $\begin{array}{l}\text { Afford the task of high-tech } \\
\text { innovation; } \\
\text { Training for people }\end{array}$ & $\begin{array}{l}\text { Distance from farmers; } \\
\text { High cost; } \\
\text { Parmers' Economic }\end{array}$ \\
\cline { 2 - 3 } Associations & $\begin{array}{l}\text { Direct interests linkages with } \\
\text { farmers; }\end{array}$ & $\begin{array}{l}\text { Potential risk of elite } \\
\text { dominant structure; }\end{array}$ \\
& $\begin{array}{l}\text { Base for information service; } \\
\text { Traditional channel of } \\
\text { information dissemination }\end{array}$ & Lack of institution building \\
\cline { 2 - 3 } Farmer households & $\begin{array}{l}\text { Direct interests linkages with } \\
\text { farmers; }\end{array}$ & Lack of resources; \\
& $\begin{array}{l}\text { Traditional channel of } \\
\text { information dissemination }\end{array}$ & Scattered, poor and weak \\
& &
\end{tabular}

In the developing process, different developing entities have different interests and objectives. While compared with other entities, farmers' own organizations have the most direct interests' linkages with local individual farmers. This is not to say that the roles played by other entities are not important, from an interest linkage point of view, Farmers' Economic Associations are more direct entry point. Further more, different entities 
should enhance cooperation with each other, and build cooperative information networks, which will benefit all the stakeholders.

Fourthly, in rural areas, traditional information and communication channels carry out most of the communication among farmers. Communication happens in village meetings, market gathering places, between relatives, from community leaders, etc. The common features of these communications are usually informal, healed behind certain village political and social culture, dependable, reliable, reflect more direct question and answer opportunities. Farmers' associations own the cultural advantages and will keep the daily communication ways which farmers are familiar with. Whether new communication technologies can be employed efficiently depends on whether the technologies can be accepted by local cultures and can be introduced into and combined with traditional channels.

\section{RECOMMENDATIONS}

In summary, there are some recommendations for a current developing strategy for information-based system establishment, they are mainly on institution building, technology choice and education.

\subsection{Institution Building}

Generally speaking, an institutional improvement may compensate to some extent for the poor infrastructure conditions in poor areas. While in better infrastructure conditioned areas, it demonstrates farmer's economic cooperatives can play positive roles as the base for further establishment of an information-based system, information covering agricultural skill upgrading, and market demand and supply information. The main advantages will be further explored according to the existing experiences, in terms of responsibility, knowledge and information localization, farmers regional network, partnership, information disseminating, sharing and innovating, cost and risk, etc.

Considering the limitation of resources and rural reality, the role of government should be focused more on facilitating, which helps to establish basic infrastructure, build knowledge capacities, train farming skills and protect farmers' rights and interests. The main facilitating role should be played in combining of resources and institution building, not be confined to infrastructure building.

In terms of policy implications, the following are some recommendations of specific measures: 
- In the developing path, farmers' real needs and local diversity should be the main focus. The solution is to let farmers participate in the communication and information dissemination.

- Identify the roles of different factors in the agricultural information development processes. Farmers should be empowered in the developing processes in order to meet the realistic needs while government should act as facilitators.

- Enhance the partnerships and cooperative relationships among different factors. It is helpful to combine various information resources supplied by different factors by enhancing the partnership and cooperative relationships.

- Supply funding to cooperative associations who are dedicated to the farmers' realistic needs. Government and other sponsors have the responsibilities of recognizing and selecting the funding beneficiaries.

- Set up ICTs of supporting centers for the funded farmers' associations. Based on the sufficient finance supports and government assistances, the selected cooperative associations could be facilitating servers and networks for applying communicative online platforms to local farmers, natural villages and other sub-associations.

\section{$5.2 \quad$ Options of technologies}

Regarding the current infrastructure circumstances in poor rural areas, it is practical and feasible to adopt simple and adaptive information technologies into agricultural information system, such as mobile technology, computer networks, local television channel services and landline-based services, etc. The case studies in Guanxi province (Miao, 2008) have shown the positive roles played by landline-based services for farmers' associations. There are also some similar cases in Ningxia province. While in some better developed rural areas in the east, more advanced technologies can be considered. At the same time experiences sharing platforms should be bridged between east and west areas.

\subsection{Education for farmers}

As for challenges of ICTs mentioned before, farmers' skills have been identified as one barrier of the development of ICTs. Under the circumstances, education is the main choice for farmers' capacity building.

This study illustrates that the success of agriculture development requires a well-organized and effectively functioning information-based system, 
while agriculture information-based system design is an integrated and cooperative process. There is need to embrace human factors more in addition to infrastructure building. There are a lot of challenges in the existing information-based system. The whole process shouldn't be simplified before a timely, reliable, accurate and functional system is established.

\section{NOTES}

1.This index conclude five measurement indicators, they are the number of fixed telephone equipment per hundred households, mobile phone number, television number, computer number and radio number.

\section{REFERENCES}

Agriculture and Agri-Food Canada. An overview of e-Learning in Canadian Agriculture and Agri-business, 2003.

Cfr. UNESCO. Social Transformation in an Information Society: Rethinking Access to You and the world, 2004.

Daoliang L. Rural Informationize Development Report, China Agricultural Science and Technology Press, 2007.

Kalusopa, T. The challenges of utilizing information communication technologies (ICTs) for small-scaled farmers in Zambia, Library Hi Tech, 2005:414

Mchombu, K. Information Dissemination for Development: An Impact Study, Journal of Information Development, 2003, 19(2):111 126

Miao, J. Cuiling, G. Xiaoye, D. and Leninhan, E. Roles played in agricultural information dissemination by different actors in farmers' economic association in China, working paper for Information System in Agriculture and Forestry 2008.

Obijiofor, L. Africa's Dilemma in the Transition to the New Information and Communication Technologies, Futures, 1998, 30(5):453 462

Richardson, D. The International and Rural \& Agricultural Development: Integrated Approach, FAO, Rome, 1997.

Wapakala, W.W. The role of libraries in agriculture, SCECSAL proceedings on libraries and Their Impact on Education, Economics and Culture in Developing Countries, Tanzania Library Association, 1982.

Williams, C. and Williams, S.K.T. Dissemination of (technical) agricultural information, Journal of Administration, 1987, 13(1):87 